\title{
Emil Ślązak
}

Szkoła Główna Handlowa w Warszawie

e-mail: emil.slazak@sgh.waw.pl

\section{MODELE BANKOWOŚCI RÓWNOLEGŁEJ (SHADOW BANKING) SHADOW BANKING SYSTEMS}

DOI: $10.15611 /$ pn.2017.488.23

JEL Classification: G21; G23, G28

Streszczenie: W artykule scharakteryzowano funkcjonowanie równoległego systemu bankowego (shadow banking) jako zróżnicowanego zbioru wysoce wyspecjalizowanych podmiotów rynkowego pośrednictwa finansowego funkcjonujących poza nadzorem bankowym. Celem artykułu jest usystematyzowanie modeli systemów bankowości równoległej poprzez zaproponowanie autorskiej koncepcji ich klasyfikacji ze względu na sposób funkcjonowania, tj.: model endogeniczny, egzogeniczny i publiczny. Najbardziej rozwiniętym systemem pod względem stopnia skomplikowania procesów jest model endogeniczny, który jest efektem transformacji tradycyjnej działalności depozytowo-kredytowej banków z udziałem podmiotów inwestycyjnych. Model publiczny jest bardzo specyficzny, a jego funkcjonowanie zależy od organizacji systemu bankowego w danym kraju. Ze względu na inicjatywy regulatorów mające na celu niwelowanie ryzyka związanego z bankowością równoległą szczególnego znaczenia nabiera system egzogeniczny.

Słowa kluczowe: bank, bankowość równoległa, sektor bankowy.

Summary: The paper characterizes the shadow banking system mechanisms through a diversified set of highly specialized financial intermediaries without banking supervision. The aim of the paper is to classify models of shadow banking by the author own concept of its classification, i.e the endogenic, exogenous and public model. The most developed system in terms of complexity of processes is the endogenous model. The public model is very specific and functionally dependent on the organization of the banking system. The exogenues model is likely to strive with financial innovations.

Keywords: bank, shadow banking, bankig sector.

\section{Wstęp}

W klasycznym systemie bankowym dochodzi do transformacji zasobów kapitału poprzez wykorzystanie przez banki płynnych depozytów do tworzenia portfela kre- 
dytowego o ograniczonej płynności. W efekcie banki jako pośrednicy finansowi z dużą ekspozycją na ryzyko płynności zarządzają luką, wynikającą z odmiennej struktury czasowej i kapitałowej, pomiędzy strukturą należności i zobowiązań. $\mathrm{Z}$ tego m.in. względu banki są poddane wysokiemu i kosztownemu reżimowi regulacji związanych z tzw. siecią bezpieczeństwa (safety net).

$\mathrm{Na}$ tym tle równoległy system bankowy (shadow banking) obejmuje zróżnicowany zbiór wysoce wyspecjalizowanych podmiotów pośrednictwa rynkowego funkcjonujących formalnie poza nadzorem bankowym. Podmioty te specjalizują się w strukturyzowaniu przepływów kapitałowych związanych z ich refinansowaniem na bazie instrumentów finansowych zabezpieczonych określonymi klasami aktywów. Jednak podobnie jak banki, podmioty systemu bankowości równoległej dokonują jakościowej, ilościowej i czasowej transformacji strumieni kapitałowych. Tym samym system bankowości równoległej tworzy nowy i szybko rosnący wymiar pośrednictwa finansowego, poza bezpośrednim oddziaływaniem banku centralnego, systemu gwarancji depozytów i reżimu nadzoru bankowego.

Celem niniejszego artykułu jest usystematyzowanie modeli systemów bankowości równoległej poprzez zaproponowanie autorskiej koncepcji ich klasyfikacji ze względu na sposób funkcjonowania, w której wyróżniono: model endogeniczny, model egzogeniczny i model publiczny.

\section{Model endogeniczny}

Model endogeniczny równoległego systemu bankowego opiera się na ścisłych powiązaniach podmiotów rynków finansowych z księgami bankowymi i jest efektem systemowej transformacji modelu działalności bankowej. Tradycyjnie banki finansują swoją działalność kredytową depozytami (głównie detalicznymi), uzyskując przychody z marży odsetkowej. Ryzyko mało płynnych aktywów ma odzwierciedlenie w księgach banku do wygaśnięcia umowy kredytowej (originate to hold model). Rozwój rynku instrumentów finansowych opartych na wierzytelności kredytowej pozwolił bankom zwiększać płynność aktywów oraz transferować ryzyko do innych podmiotów poprzez wykorzystanie operacji związanych z obrotem instrumentami finansowymi, które są zabezpieczone określonymi klasami aktywów (originate to distribute model) [Nersisyan, Wray 2010]. Pod presją konkurencyjną banki zaczęły rozwijać na dużą skalę rozwiązania charakterystyczne dla bankowości inwestycyjnej, bazując na transakcjach rynkowych o wysokiej płynności i dużej elastyczności w procesie strukturyzacji ryzyka i przepływów z portfela kredytowego.

Z tego względu model endogeniczny równoległego systemu bankowego można określić jako reorganizację procesów pośrednictwa kredytowego. W miejsce funkcji zarządzania ryzykiem, banki przyjęły zadanie dystrybuowania wierzytelności kredytowych w celu ich odsprzedaży na szybko rozwijającym się rynku wtórnym. W ten sposób doszło do reorientacji procesów zarządzania bankiem, w którym de- 
partament skarbu (treasury) został podporządkowany strukturyzacji portfela kredytowego na bazie instrumentów rynkowych (portfolio management) [Duffie 2010].

Zmiana paradygmatu działalności banku z,właściciela” portfel kredytowego na rzecz ich „dystrybutora” jest inspirowana rosnącą efektywnością podmiotów shadow banking w strukturyzacji przepływów kapitałowych. W modelu endogenicznym pośrednictwo kredytowe opiera się na funkcjonalnym podziale poszczególnych etapów procesów kredytowania z transzowaniem wierzytelności kredytowych w celu oddzielania i odsprzedaży ryzyka kredytowego w odrębnych operacjach pozabilansowych z minimalnym wyposażeniem kapitałowym wyspecjalizowanych wehikułów inwestycyjnych. Ze względu na międzynarodowy wymiar działalności bankowej poszczególne procesy często zachodzą w różnych jurysdykcjach prawnych [Acharya i in. 2013].

Model endogeniczny systemu bankowości równoległej wykorzystuje bankowe wierzytelności kredy towe, które są transferowane do podmiotów rynku pieniężnego korzystających z niepublicznych instrumentów rynku dłużnego (ABCP conduits). Podmioty te przejmują aktywa od jednego (formuła single-seller) lub wielu banków (formuła multi-seller) w celu reorganizacji portfela wierzytelności, tworząc zbiór o jednorodnych właściwościach. Zbiór wierzytelności kredytowanych służy do zabezpieczania emisji instrumentów opartych na aktywach (assets backed securities - ABS). Emisja jest organizowana przez spółki inwestycyjne pełniące funkcję dealerów i brokerów na rynku instrumentów finansowych lub organizujące procesy tzw. trójstronnego repo. W przypadku ABS ma miejsce mechanizm podziału emisji na transze zależne od terminu wykupu, przy czym transze zapadające jako pierwsze należą do instrumentów rynku pieniężnego. W praktyce oznacza również rolowanie ryzyka, gdyż spółki emitujące ABS mają zapewnione finansowanie krótkoterminowe na bazie repo czy niepublicznych instrumentów finansowych rynku pieniężnego zabezpieczonych aktywami - ABCP) [Nersisyan, Wray 2010].

W kolejnym etapie dochodzi do zintegrowania poszczególnych emisji ABS w portfelu strukturyzowanych funduszy inwestycyjnych (SIV - structure investment vehicle), które pozyskują finansowanie na bazie transakcji repo oraz swap służących do transferowania ryzyka wierzytelności (total return swaps). Strukturyzowana pula ABS stanowi podstawę jednej lub kilku emisji nowej klasy instrumentów dłużnych CDO (Collateralized Debt Obligation) z wyróżnieniem transz o różnej rentowności zależnej od priorytetu wykupu przez SIV, a tym samym ryzyka niewykonania zobowiązania przez emitenta. Poprzez transzowanie emisji CDO, SIV dokonują kolejnej transformacji kapitału i płynności w celu dostosowania poziomu ryzyka do preferencji inwestorów. Równocześnie CDO mogą służyć tworzeniu kolejnych emisji instrumentów dłużnych, co w praktyce prowadzi do bardzo szybkiego rozwoju rynku kosztem jego transparentności. Swoją działalność strukturyzowane fundusze inwestycyjne (SIV) opierają na finansowaniu poprzez transakcje repo lub/i emisje ABCP oraz MTN (medium term notes) [Pozsar i in. 2010]. 
Proces strukturyzacji wierzytelności w modelu endemicznym nie musi obejmować wszystkich powyższych etapów, gdyż może być sfinalizowany już na etapie sprzedaży puli wierzytelności kredytowych lub emisji pierwotnych CDO. Najogólniej występuje zasada, że im niższa jakość wierzytelności tworzących zabezpieczenie emisji, tym więcej mechanizmów jest wykorzystanych w celu transformacji ryzyka kredytowego w celu dopasowania do poziomu ryzyka znamiennego dla funduszy inwestycyjnych rynku pieniężnego. Oznacza to też, iż w wyniku transformacji pośrednictwa kredytowego mało płynne, długookresowe wierzytelności kredytowe o skumulowanej ekspozycji na ryzyko niewykonania zobowiązania zostają zastąpione krótkoterminowymi wysoce płynnymi instrumentami dłużnymi o rozproszonym ryzyku o charakterze zbliżonym do depozytów bieżących.

Endogeniczna bankowość równoległa pozwala na transformację ryzyka kredytowego i płynności podobnie jak w tradycyjnym modelu pośrednictwa bankowego. Jednakże transfer wierzytelności przy wykorzystaniu instrumentów finansowych wyróżnia się wyższą rentownością przy znacznie niższych wymaganiach kapitałowych. Koncentracja ryzyka płynności w księgach banków (konieczność wsparcia płynnościowego) z tytułu bardzo różnorodnego zestawu podmiotów pozabilansowych prowadzi do systemowego kryzysu płynnościowego [Acharya i in. 2013]. Skala potrzeb płynnościowych w sytuacji nagłej utraty finansowania na podstawie dotychczasowych instrumentów rynkowych oraz problemy z płynnością rynku instrumentów finansowych w przypadku rozwiniętej sekurytyzacji szybko przekracza wartość płynnych aktywów bankowych, inicjując zaburzenia systemowe. Tym samym należy stwierdzić, iż dywersyfikacja pośrednictwa kredytowego poprzez przeniesienie procesów zarządzania ryzykiem w obszar usług pośrednictwa rynkowego nie prowadzi do obniżenia ryzyka kredytowego w bankach, lecz do jego formalnego rozproszenia wśród uczestników rynku. Ryzyko wciąż faktycznie pozostaje w sektorze bankowym, generując problemy agencji w sytuacji znaczącej asymetrii informacji.

Możliwość stałego wsparcia płynnościowego przez banki jest niezbędnym elementem stabilności funkcjonowania endogenicznego systemu bankowości równoległej. Jednakże duże rozproszenie i niska transparentność ryzyka w sytuacjach kryzysowych wpływają na wzrost nieufności stron transakcji i prowadzi do kumulowania płynności (liquidity hoarding) [Brunnermeier, Pedersen 2009]. W całym systemie tylko banki mają dostęp do „okna dyskontowego” w banku centralnym oraz korzystają z instytucjonalnej sieci bezpieczeństwa, podczas gdy równoległy system bankowy znajduje się poza procedurami przywracających stabilność finansową.

\section{Model egzogeniczny}

Model egzogeniczny bankowości równoległej opiera się na systemie funkcjonalnych współzależności pomiędzy podmiotami funkcjonującymi niezależnie od działalno- 
ści depozytowo-kredytowej banków. Tym samym ten model wykorzystuje przepływy kapitałowe prowadzące do transformacji ryzyka przez dealerów i brokerów rynkowych na bazie aktywów niebankowych instytucji finansowych (np. firmy pożyczkowe na rynku consumer finance, fundusze inwestycyjne, zakłady ubezpieczeń czy fundusze emerytalne). Brak powiązań z systemem bankowym oznacza, że podmioty inwestycyjne nie mają dostępu do mechanizmów wsparcia płynnościowego znamiennego dla banków oraz prewencyjnych mechanizmów nadzorczych w zakresie ryzyka systemowego.

Podobnie jak w modelu endogenicznym, model egzogeniczny bankowości równoległej wykorzystuje globalny system powiązań bilansowych i pozabilansowych podmiotów rynku finansowego opierających się na strukturyzacji przepływów kapitałowych z transformacją czasu i transformacją ryzyka. Ważnym czynnikiem rozwoju modelu egzogenicznego bankowości równoległej stał się nie tyle arbitraż regulacyjny (jak w modelu endogenicznym), ile ponadprzeciętna rentowność strukturyzowanych wierzytelności. Wyróżnikami egzogenicznego modelu bankowości równoległej jest proces stricte rynkowego pośrednictwa kredytowego oparty na działalności brokerskiej i dealerskiej w sposób niezależny od akcji kredytowych banków i ich działalności depozytowej. Ważnym aspektem architektury egzogenicznego systemu bankowości równoległej jest również wykorzystanie kanałów efektywnego oddzielenia ryzyka od portfela wierzytelności i jego transferu do szerokiego grona inwestorów.

Wykorzystanie modelu dealera/brokera w modelu egzogenicznym wynika z aktywnej i specjalistycznej działalności inwestycyjnej na rynkach finansowych w obszarze usług ubezpieczeniowych i inwestycyjnych. Wówczas funkcjonowanie brokerów/dealerów skupia się na refinansowaniu działalności spółek matek na rynkach finansowych poprzez korzystanie z ich wysokiej wiarygodności jako podmiotów o znacznych aktywach długoterminowych. Tym samym dealerzy i brokerzy bazują na wierzytelnościach podmiotów quasi-bankowych, dzięki czemu inicjują proces sekurytyzacji różnych wierzytelności, w tym kredytowych, przejętych na rynku wtórnym.

W celu zabezpieczenia płynnościowego agregowanych wierzytelności kredytowych usługi prowadzą ABCP conduit (zarówno w formule single-, jak i multiseller). W większym też stopniu niż w modelu egzogenicznym do refinansowania aktywów wykorzystywane są transakcje warunkowego zakupu aktywów. Wysokie znaczenie repo jest związane z wykorzystywaniem operacji wykazywanych w księgach handlowych bez konieczności tworzenia spółek celowych do finansowania puli wierzytelności w sekurytyzacji opartej na ABS i CDO [Pozsar i in. 2010].

Podmiotami o wysokiej specjalizacji w egzogenicznym modelu bankowości równoległej są niezależne multi-seller conduits skupujące wierzytelności kredytowe na rynku wtórnym, fundusze hedge rynku kredytowego oraz specjalne spółki celowe SIV [Da 2012]. Podmioty te specjalizują się w obsłudze kredytowej na rynku motoryzacyjnym, usługach leasingowych i kredytów na finansowanie franszy- 
zy. Ich model sekurytyzacji przebiega odmiennie od schematu tworzenia portfela w celu odsprzedaży (originate-to-distribute), ponieważ wykorzystują portfele wierzytelności, które są wykazywane w skonsolidowanych raportach finansowych spółek matek. Co więcej, ponieważ bezpieczeństwo finansowe ma miejsce tylko wtedy, gdy ma oparcie w wiarygodności spółek matek, aktywność dealerów/brokerów jest mocno uwarunkowana płynnością rynków, co oznacza znaczne fluktuacje w wycenie aktywów szczególnie w okresach zwiększonej awersji do ryzyka.

Innym wyróżnikiem modelu egzogenicznego jest stworzenie alternatywnego do bankowego modelu transferu ryzyka dla szerokiego spektrum wierzytelności. Ubezpieczyciele na rynku wierzytelności hipotecznych obniżają ryzyko kredytowe dla inwestorów kupujących instrumenty finansowe, zwiększając jakość aktywów. Podmioty inwestycyjne ubezpieczają ryzyko poszczególnych transz ABS, fundusze hedgingowe rynku kredytowego czy zakłady ubezpieczeń przejmują za wynagrodzeniem ryzyko emisji CDO, a nawet ekspozycję na ryzyko podmiotów inwestujących na rynku ABS w swapach kredytowych (CDS). W ten sposób dealerzy/brokerzy, podobnie jak banki, dokonują transformacji ryzyka w relacjach z kredytobiorcami i deponentami, zwiększając istotnie jakość emisji i wpływając na rentowność inwestycji możliwością niwelacji ekspozycji na ryzyko.

\section{Model publiczny}

Wysoka wiarygodność podmiotów związanych z finansami publicznymi wspiera rozwój rynku kredytowego, co w USA przez długi czas oznaczało emisję i handel instrumentami finansowymi teoretycznie pozbawionymi ryzyka (tj. o najwyższym ratingu). Publiczny równoległy system bankowy bazuje na procesach pośrednictwa kredytowego banków poprzez ich wsparcie płynnościowe na wtórnym rynku wierzytelności w celu obniżenia ryzyka i kosztu kapitału. Celem głównym podmiotów jest wspieranie realizacji polityki gospodarczej państwa (np. w USA Federal Home Loan Mortgage Corporation i Federal National Mortgage Association), a celem operacyjnym - zapewnienie warunków do szybkiego rozwoju wielkości podaży kredytów na rynku nieruchomości. Dlatego też wyposażenie kapitałowe publicznego modelu bankowości równoległej oraz zapewnienie przesłanek stabilnego funkcjonowania są związane ze wsparciem władz publicznych [Acharya 2012].

W odróżnieniu od banków, podmioty równoległego systemu bankowego nie podejmują aktywnej działalności kredytowej opartej na rynku depozytowym. Do refinansowania działalności jest wykorzystywana emisja instrumentów dłużnych na rynkach hurtowych krótko- i długoterminowych. Koszt pozyskania kapitału jest znacznie niższy, gdyż emisje są wspierane poręczeniami władz publicznych. Formalnie jednak instytucje publiczne równoległego systemu bankowego nie są uwzględniane $\mathrm{w}$ oficjalnych rachunkach finansów publicznych, a system poręczeń i gwarancji stanowi pośrednie zobowiązania władz publicznych o charakterze implicite. 
Podobnie jak w poprzednich modelach, również tutaj dochodzi do transferu wierzytelności kredytowych z sektora bankowego i ich przekształcenia w zbiór aktywów z wykorzystaniem jakościowej i terminowej transformacji kapitału. W ten sposób dochodzi do redukcji ryzyka kredytowego wynikającej z wierzytelności bazowych, co zachęca inwestorów instytucjonalnych do zaangażowania kapitału $\mathrm{w}$ bezpieczne instrumenty finansowe o relatywnie wysokiej rentowności (MBS). Niektóre z wyemitowanych instrumentów zmieniają swój początkowy status sekurytyzacji pierwotnej poprzez emisję wtórnych zróżnicowanych transz instrumentów dłużnych opartych na aktywach pierwotnych - tzw. resekurytyzacja (Collateralized Mortgage Obligation - CMO). Znaczenie publicznego systemu równoległego ma charakter lokalny i jest zależne od porządku prawnego danego państwa.

\section{Zakończenie}

Pomimo stosunkowo krótkiego okresu funkcjonowania systemu bankowości równoległej cechuje go bardzo szybki rozwój, który na krótko został zahamowany kryzysem finansowym lat 2008-2009. Niewątpliwe największe znaczenie ma najbardziej rozwinięty system endogeniczny. Jednakże ze względu na inicjatywy regulatorów (m.in. Rady Stabilności Finansowej - Financial Stability Board), mające na celu niwelowanie ryzyka związanego $\mathrm{z}$ bankowością równoległą $\mathrm{w}$ sektorze bankowym, obserwuje się duży wzrost operacji finansowych w ramach modelu egzogenicznego (m.in. w USA czy Chinach). W przyszłości można oczekiwać wsparcia modelu egzogenicznego poprzez również dynamiczny rozwój podmiotów związanych z nowymi technologami informatycznymi (Fintech), które podejmują się samodzielnego finansowania nie tylko klientów detalicznych, lecz także sektora MŚP.

\section{Literatura}

Acharya V.V., 2012, Governments as Shadow Banks: The Looming Threat to Financial Stability, Texas Law Review, vol. 90, issue 7, s. 1746-1774.

Acharya V., Schnabl P., Suarez G., 2013, Securitization without risk transfer, Journal of Financial Economics, vol. 107, s. 515-536.

Brunnermeier M.K., Pedersen L.H., 2009, Market liquidity and funding liquidity, Review of Financial Studies, vol. 22, issue 6, s. 2201-2238.

Da W., 2012, Shadow Banking System in the US: Development, Operation, Impact and Regulation, Studies of International Finance, no. 1, s. 001-022.

Duffie D., 2010, The failure mechanics of dealer banks, The Journal of Economic Perspectives, vol. 24, no. 1, s. 51-72.

Gray R., Owen D., Sopher M.J., 1998, Setting up a control system for your organization, Nonprofit World, vol. 16, no. 3, s. 65-76. 
Nersisyan Y., Wray L. R., 2010, The global financial crisis and the shift to shadow banking, Working Paper, Levy Economics Institute, no. 587, s. 3-30.

Pozsar Z., Adrian T., Ashcraft A., Boesky H., 2010, Shadow banking, Report, Federal Reserve Bank of New York, no. 458, s. 1-35. 